\title{
Concentration in Botswana's Banking Sector
}

\section{T Kayawe}

Botswana Institute for Development Policy Analysis

\section{A Amusa}

Department of Economics, University of Pretoria

\section{ABSTRACT}

This study examines the degree of competition and efficiency within the commercial banking sector of Botswana. By applying the Herfindahl index, the paper provides an empirical methodology for assessing competition and market concentration among commercial banks. The study also utilises alternative measures of bank input and output by developing simple descriptive indices to assess the level of efficiency in Botswana's banking sector. Overall, the results indicate that the implementation since 1989, of policies to liberalise and reform financial sector activities has contributed to increased competitiveness and efficiency amongst Botswana's commercial banks.

JEL D20, D40, G21

\section{INTRODUCTION}

Over the past two decades, many of the heavily indebted developing countries have undertaken extensive reforms to operations conducted by their financial institutions. In particular, transforming activities of commercial banks have been of paramount importance to countries implementing structural adjustment programmes. This importance is mainly due to the intermediation role which an efficient banking sector plays in ensuring that funds are directed towards efficient investment which is a key factor in stimulating economic growth. Similarly, the government of Botswana has since 1989 introduced liberalisation and reform policies primarily aimed at increasing efficiency of operations and the intermediation function of the country's financial institutions (Jefferis, 1991 and Brownbridge \& Harvey, 1998).

The changes enacted by policymakers have focused on the key aspects of (i) allowing greater market determination of interest rates as a means of encouraging a greater degree of financial deepening, and (ii) raising the level of competition within the financial sector through the licensing of new financial institutions. In recent years, the relaxation of financial regulations has enabled 
new players to establish a presence in Botswana's commercial banking sector, an outcome that has prompted existing banks to consolidate and rationalise their various operations. From a policy perspective, the increase in size and numbers of commercial banks in Botswana should create and enhance greater competition, which, is viewed as a key determinant of the price and quality of commercial banks' output and services. Accordingly, it is expected that with increased competition, there will generally be a move towards greater efficiency and a gradual decline in supernormal profits. This contrasts with the situation that prevails in uncompetitive markets where there is less incentive to pursue efficiency and product development.

Building on the study conducted by Roberts (1994), the aim of this paper is to assess the nature and extent of market concentration within Botswana's commercial banking sector. Such an analysis will provide for an evaluation of the effect that financial deregulation has on encouraging competition and diversifying the range of products that banks provide to the general public. A revision and extension of Roberts' study is essential for a number of reasons. These include, amongst others, (i) the recent increase in the number of operating commercial banks that has expanded the availability of the revised data set on banking sector operations and (ii) take-overs, mergers and expansion activities in Botswana's financial sector that have had the effect of significantly changing assets and liabilities of commercial banks, thus providing this study with encompassing measures of banks' inputs and outputs. In addition to the above, the changes in operations undergone by Botswana's banking system provides a means of evaluating whether adopted liberalisation policies have had their intended effects.

The remainder of the paper is organised as follows: Section 2 provides a chronology of events in Botswana's commercial banking sector since its inception and also includes an assessment of the impact of policy changes on the banking sector. Section 3 reviews literature on theoretical application and empirical evaluation of market concentration in the context of the banking sector, and in the process highlights some problems regarding quantification of banking services. Section 4 discusses and provides measures of market concentration in Botswana's banking sector. In turn, these measures are utilised in evaluating the impact of increased liberalisation and competition on productivity and efficiency in commercial banks. Section 5 gives concluding comments and policy recommendations. 


\section{DEVELOPMENT OF THE FINANCIAL SECTOR IN BOTSWANA}

This section provides a historical perspective of regulation of the banking sector in Botswana and the increase in commercial bank competition in more recent years.

\subsection{Historical perspective}

At independence in 1966, two banks of British origin, namely, Barclays and Standard Chartered, dominated Botswana's commercial banking sector. Until April 1975, both institutions operated as branches of their respective head offices located in South Africa. The lack of a central bank in Botswana meant that banking policies related to setting of interest rates and liquidity and capital requirements were subject to the policy regulations enacted by the South African Reserve Bank (SARB). Botswana's membership of the Rand Monetary Area (RMA) ${ }^{1}$ also meant that in cases of transactions with non-member countries of the RMA, commercial banks applied South African foreign exchange regulations (Brownbridge \& Harvey, 1998).

The discovery of diamonds in the early 1970s gave Botswana's government impetus to implement a number of financial policies aimed at ensuring that export earnings were properly managed in accordance with economic objectives. Both Barclays and Standard Bank became locally incorporated firms in $1975^{2}$. In the following year, the central bank, the Bank of Botswana (the $\mathrm{BoB}$ ), was established and the national currency, the Pula introduced. The legislative powers granted to the $\mathrm{BoB}$ at its inception effectively ushered in the era of banking regulation as the BoB independently set interest rates on banks' deposits and lending, fixed domestic liquidity requirements and implemented exchange control regulations. Exchange controls were primarily enacted to curb imported inflation from its largest trading partner, South Africa.

Concerned with the lack of banking competition and long established oligopolistic features of commercial banking in Botswana, the government enacted a number of financial laws and regulations to promote competition and enhance the efficiency of intermediation. In 1982, a subsidiary of the Bank of Credit and Commercial International (BCCI), the Bank of Credit and Commerce Botswana Limited (BCCB) opened its doors to the public in Botswana. Following the collapse of the BCCI, the BoB temporarily managed the BCCB until its take over by First National Bank in 1991. After the BCCB, Zimbank Botswana Limited (ZBL) became the first foreign bank to apply for a banking license and was incorporated in Botswana in 1990. Owing to loss making operations and accumulation of substantial bad debts, ZBL was eventually taken over by First National Bank Botswana (FNBB) in September 1994. 
Between 1991 and 1992, three more foreign-owned commercial banks began operations in Botswana. The first two, First National Bank (FNB) and Union Bank were wholly South African owned. FNB was incorporated in Botswana and became FNBB before it acquired BCCB. The third new bank, ANZ Grindlays, had its Africa wide operations purchased by Standard Bank of South Africa and was merged with Union Bank in 1992 to form Stanbic Bank. At present, the banking sector in Botswana consists of five commercial banks (namely Barclays, Standard, FNBB, Stanbic and Bank of Baroda) and two investment banks (Investec and African Banking Corporation).

\subsection{Changes to financial regulations}

\subsubsection{Interest rate policy}

At its inception, the BoB adopted a restrictive monetary policy by setting the prime lending rate and the commercial bank interest rate for each class of deposits. The setting of interest rate ceilings meant that for much of the 1970s and 1980s, real interest rates were negative. The restrictive measures were, to a large extent, influenced by substantial earnings from diamond exports that resulted in massive increases in the level of savings with commercial banks. The policy of low interest rates was thus intended to encourage adequate levels of investment and to stimulate economic growth.

As stated earlier, the earnings from diamond exports provided for substantial private and public sector revenues that translated into rapidly increasing inflows of savings into the commercial banking system. Between 1980 and 1990, commercial bank deposits grew at an average of 23 percent a year. Despite this growth, commercial banks focused on providing mainly short-term loans and financing for working capital. These factors along with an unwillingness to finance large long-term projects (especially the development of small and medium scale enterprises in the private sector), meant that the outflow of loanable funds did not match the inflow of savings, leaving commercial banks awash with excess liquidity. The build up in excess liquidity prompted commercial banks to decline large fixed term deposits at advertised rates, as the deposits would have been re-deposited with the BoB at a loss. To prevent banks from turning away investors with large, interest-bearing assets ${ }^{3}$ the BoB became a deposit taking institution of last resort. In 1989, this function entailed the BoB offering the general public access to an overnight call deposit facility with a minimum balance of P150 000 (Bank of Botswana, 1993) ${ }^{4}$.

In many respects, the BoB's policy of being a "banker of last resort" effectively caused a partial failure in the intermediation function of the banking sector (Brownbridge \& Harvey, 1998). By the late 1980s, the government began 
expressing concern that negative real interest rates would eventually act as a disincentive for savings and promote borrowing for consumption rather than for investment purposes. Like the government, the BoB viewed the policy of setting interest rates, and regulating commercial bank charges as having two negative effects. Firstly, they enhanced the channelling of surplus deposits towards inefficient economic activities and secondly, these policies distorted the BoB's monetary management functions ${ }^{5}$. These factors led the BoB in September 1989 to abandon the low interest policies, and instead grant commercial banks independent means to determine their interest rates, fees and charges.

In a bid to absorb excess liquidity and facilitate a market-oriented approach in determining interest rates, the BoB in May 1991 discontinued the call facility and introduced Bank of Botswana Certificates (BoBCs) ${ }^{6}$. A related consequence of the excess liquidity phenomenon is that commercial banks have had very little need to use the BoB as a "lender of last resort". In many respects, this has virtually rendered the main instrument of domestic monetary policy, the BoB's bank rate, a somewhat inactive and ineffective policy tool. To address this, the BoB has over the years utilised moral persuasion to convince commercial banks to adjust their lending rates in response to changes in the $\mathrm{BoB}$ bank rate. Thus, the BoB's move from a regulated to market-based approach in determining interest rate policy has had the overall effect of making commercial banks regard the BoBCs rate and $\mathrm{BoB}$ bank rates as key signals for setting their own interest rate levels.

\subsubsection{Foreign exchange controls}

Since the mid 1990s, Botswana's Government has adopted a policy of continuous liberalisation of foreign exchange controls. Prior to the relaxation of exchange controls, residents of Botswana were forbidden from holding bank accounts abroad. This restriction acted as a hidden tax, as companies and individuals could not shift their assets into foreign markets where interest rates were higher than in Botswana (Brownbridge and Harvey, 1998). Exchange controls had the effects of (i) permitting commercial banks easier access to captive funds due to banks being the only institutions offering foreign exchange services to individuals and firms; (ii) ensuring that banks were able to charge profitable commissions on foreign exchange transactions, and (iii) removing competition amongst banks in the provision of foreign exchange services. The relaxation of exchange controls have now allowed for dual listings between the Botswana Stock Exchange (BSE) and foreign stock markets. This has resulted in the broadening and deepening of the local share market as well as an increase in liquidity of domestic firms. 


\section{LITERATURE REVIEW}

\subsection{Market structure and efficiency}

Most of the literature on competition relates to the debate between two conflicting paradigms, namely the structure-conduct-performance (SCP) and the efficiency structure (ES) paradigms. The SCP or the market concentration doctrine suggests that high market concentration leads to high prices and profits, both of which promote market power to the detriment of social welfare. According to this hypothesis, high market concentration also facilitates collusion in the market, enabling firms to approximate a monopoly (joint profitmaximisation) solution. Such a solution is more pronounced the higher the market concentration, where evidence of market concentration is given by a positive correlation between profitability and concentration. Proponents of the market concentration hypothesis conclude that high concentration leads to losses in social welfare associated with monopolistic restrictions on output, and that regulatory measures need to be put in place to limit or reduce the amount of market concentration. Taking a contrary view, the ES hypothesis posits that the standard oligopoly theory ignores both potential and actual entry, and assumes that the existing firms in concentrated markets have the market power to earn supernormal profits. This assumption holds only if there are barriers to entry and therefore, no threat of potential entry from firms waiting to enter the market. However, in cases of non-restrictions to entry, firms in a concentrated market will seek ways to ensure that they earn normal profits in order to deter entry, and keep regulators away from the industry ${ }^{7}$.

The market concentration doctrine views the positive relationship between profitability and concentration as a causal link that runs from concentration to collusion to monopoly profits. The efficiency school however views this relationship differently. Demsetz (1973) argues that profits are a sign of efficiency rather than monopoly power within a market. The positive relationship between profit and concentration is not indicative of the latter causing the former, but rather because efficiency causes both. If firms in a market possess superior efficiency, they will most likely tend to be large relative to their competitors. This type of relative dominance results in both high market concentration and high profits. Therefore, a positive profitability-concentration relationship will result from superior efficiency independent of any market power effects (Clarke, 1985). 


\subsection{Market concentration and performance in the banking sector}

\subsubsection{The case against monopoly}

The case against monopoly is based on its effects on the welfare of consumers. It is argued that by restricting output, monopolies lead to social welfare loss, a loss termed dead-weight loss or allocative inefficiency. A number of studies have been conducted to establish the amount of the loss to society arising from monopolisation of markets (see for example, Harberger, 1959). Leibenstein (1966) argues that losses arising from monopolisation of markets are small as allocative inefficiency involves only net marginal effects. With every firm assumed to purchase and utilise all of its inputs efficiently, what is left is the consequence of price and quantity distortions. Thus, on a relative basis, price and quantity distortions are small.

Based on the above, Leibenstein suggests a different type of inefficiency termed $\mathrm{X}$-inefficiency. Leibenstein also notes that losses due to X-inefficiency may be large relative to those from allocative inefficiency. For given units of inputs, Xinefficiency is connected with the possibility of variable performance, and this connection arises for three reasons. First, labour contracts are incomplete; second, the production function is not completely known and third, not all inputs are marketed and if marketed, are not equally available to all buyers. Leibenstein thus suggests an approach to the theory of the firm that does not depend on the assumption of cost minimisation by all firms. This approach implies that the level of unit cost depends in some measure on the degree of $\mathrm{X}$ efficiency, where X-efficiency depends on the degree of competitive pressure as well as on other motivational factors. The overall conclusion reached by Leibenstein is that firms and economies do not operate on the production possibility surface consistent with their resources. Instead, they actually work on a production surface that is well within the production possibility curve. Leibenstein contends that the amount to be gained by increasing allocative efficiency is trivial while the amount to be gained by increasing X-efficiency is frequently significant.

\subsubsection{Empirical evidence}

The arguments outlined in Section 3.2.1 above apply to industries in general. However, there have also been a number of studies examining these issues with specific focus on the banking industry. Gilbert (1984) argues that most studies on bank market structure devote very little discussion to the theoretical justification of estimated equations, and also adopt the market concentration doctrine approach as the basis of their analysis. However, a major problem in relation to other industries, concerns the identification of firm output in the 
banking sector. Based on the understanding that banking sector output(s) is not homogeneous, some studies use advances (or loans) as output while others utilise bank deposits as an alternative measure. However, the prices of these measures of output are dependent on the interest rate charged on loans ${ }^{8}$; in turn interest rates charged are a function of factors such as the type of collateral and repayment terms.

As noted by Smirlock (1985), studies undertaken on the relationship between bank market concentration and profitability contain so many inconsistencies that they provide inadequate evidence of a positive association between concentration and performance in banking. The existing banking literature suggests that the quantitative weakness of the concentration-profitability relationship is due to market concentration allowing managers to behave in a manner inconsistent with profit maximisation. The inconsistent behaviour may take the form of additional on-the-job consumption by managers (expensepreference behaviour) or risk reduction to permit the "quiet life". To the contrary, Smirlock argues that owners would permit increased managerial perquisite consumption as concentration increases, only if concentration and monitoring costs are positively related. Market concentration alone is unlikely to permit managerial risk reduction inconsistent with owner wealth maximisation. However, if supernormal profits attract adverse regulatory attention, then some risk reduction may be in the owners' interests.

Smirlock further posits that differential efficiency is not the only possible cause of a market share-profitability relationship. Higher profits can result not only from lower costs but also from higher prices. Therefore, market share may capture market power stemming from product differentiation, i.e., banks with large market share may have higher quality products that allow them to charge higher prices and earn higher profits. Although distinguishing between the efficient structure and the product differentiation hypothesis using profit data might be problematic, some insight into distinguishing between both theories can be gained through the application of service charges/prices to measure performance. In an equation including both market share and concentration as regressors and using price as a proxy for measure performance, the market concentration doctrine predicts a zero coefficient on market share and a positive coefficient on concentration. On the other hand, the efficient structure hypothesis predicts a zero coefficient on both market structure variables. In the case of the product differentiation hypothesis, a positive coefficient on market share and a zero coefficient on concentration are predicted. Smirlock however argues that most measurements of prices generally provide poor proxies of actual prices. On the basis of his results, Smirlock states that the assumption that concentration in banking markets results in monopoly profits being earned does not hold. 
Smirlock thus suggests that effects of concentration as reported in previous studies are spurious, and in all likelihood can be attributed to a correlation between profitability and market share variables. On this basis, the link between profitability and market share can be regarded as providing support for the efficient structure hypothesis over the market concentration doctrine. Furthermore, and consistent with Smirlock's own results, is the hypothesis that market concentration is not a signal of collusive behaviour but rather the superior efficiency of the leading firms. Therefore, policies placing greater emphasises on regulatory actions that penalise this efficiency and/or encourage efficient banks to be less efficient, may also be decreasing economic welfare.

Contrary to Smirlock's superior efficiency argument, a number of studies suggest that where few banking organisations are in direct competition in several market areas, they may agree (or collude) to limit their rivalry in all market areas where they are represented. In cases involving antitrust issues and restrictions on interstate banking in the United States, the possibility of collusion has been used as a strong basis to argue that concentration among banks remains a relevant measure of structure ${ }^{9}$. Bell and Murphy (1969) note that while studies attempting to measure the effect of changes in market concentration on prices of various bank services indicate that cost has a significant influence on prices of regular demand deposits and interest rates charged on business loans, such studies were at best inconclusive. In addition, there was a failure to explicitly consider the cost of production of particular bank services, the adopted proxy of output was not a homogeneous measure, and there was lack of clarity on the measure of concentration utilised.

Given the above shortcomings, Bell and Murphy (1969) use bank demand deposits as the preferred measure of output. The preference for banks' demand deposits is premised on the argument that the holding of such deposits represent a unique service offered by the commercial banking industry. Using various measures of concentration to test the effect of concentration on the price of demand deposits, Bell and Murphy (1989) state that where economies of scale exist in banking, an increase in the average size of a firm within a market area due to merger activities will lower both costs and prices. It is however possible that mergers could result in increased concentration and higher prices. The net effect will then depend on the relative magnitude of these two divergent influences. The overall conclusion reached by Bell and Murphy is that concentration has a positive and significant effect on price.

Gilbert (1984) highlights the neglect, by many studies, in examining the important role that regulation plays in bank performance. In light of this, Gilbert proposes two forms of regulation that may affect bank performance. First, the setting of ceiling interest rates influences the measures of bank 
performance independently of local market concentration. This effect is especially significant when market interest rates are high relative to these ceiling rates. Second, entry regulation plays an important role in determining the level of market concentration. With restricted entry the degree to which the pricing and availability of services reflects monopolistic and competitive behaviour is determined by local firms already in the market. However, with unrestricted entry into the banking system, pricing of banking services would be influenced by the threat of entry by firms not already in the market, irrespective of the existing structure of the market. Therefore, eliminating entry regulation would tend to weaken the structure-performance relationship in banking markets.

\section{PERFORMANCE ANALYSIS}

\subsection{Concentration and performance}

Following Roberts (1994), the Herfindahl index is used to measure the extent of market concentration ${ }^{10}$. As conventional measures of output applied to industrial firms are not applicable to banks, we utilise deposits with the banking sector as a proxy measure of market size. Mathematically, the index is expressed as

$\mathrm{H}=\sum_{\mathrm{i}=1 . ., \mathrm{n}}\left(\mathrm{D}_{\mathrm{i}} / \mathrm{TD}\right)^{2}$

where, TD represents total deposits with all commercial banks and D is deposits with bank i. Figure 1 provides a graphical representation of the trend in market concentration within Botswana's commercial banking sector. The figure shows that since 1990, concentration in the banking industry has been on a steady decline. This decline may be linked with the occurrence of significant increases in the number of licensed banks. This increase led to a rise in competition within the banking sector as new banking firms sought to capture a portion of the market from existing firms. For example, FNNB competed aggressively in retail banking and grew rapidly through acquisitions and mergers while Stanbic focused its operations on providing credit to subsidiaries of Botswana-based South African companies ${ }^{11}$. 
Figure 1 Profitability and concentration index, 1989-2001 (1989=100)

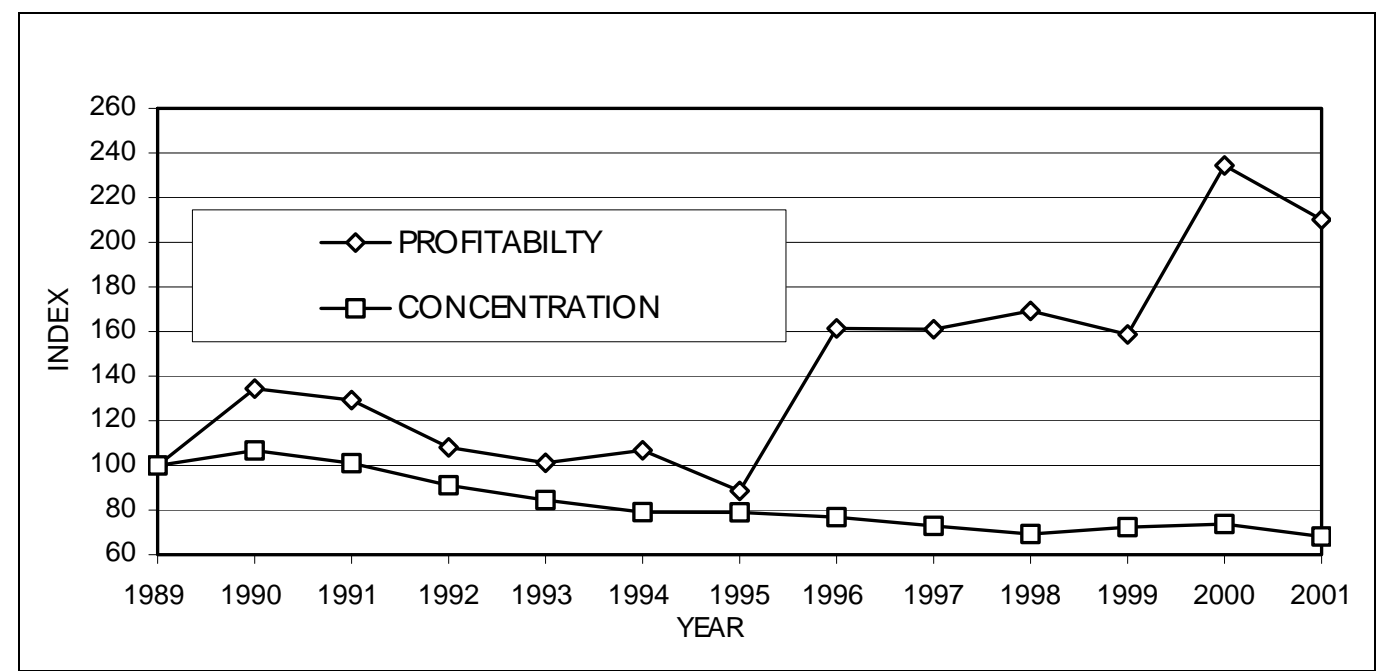

Source: Authors' own calculations

\subsection{Profitability}

In Figure 1 the concentration index and the profitability index ${ }^{12}$ are plotted against time. The graph indicates that apart from a slight increase in 1994, profits fell between 1990 and 1995 . The sharp increase in profitability between 1995 and 1997 could be attributed to the rationalisation of operations (which included the automation of banking operations) and substantial retrenchment of staff carried out by the country's two largest banks, Barclays and Standard Chartered, factors that resulted in substantial reductions to labour and operating costs and enhanced the profitability of banking operations. The rise in profitability could also be traced to a number of other policy changes. These include the lifting of interest rate ceilings that enabled commercial banks to charge higher interest rates to risky borrowers; the introduction of BoBCs which permitted banks to receive relatively high returns on their excess liquidity deposits at the BoB; the progressive abolition of exchange rate controls that allowed commercial banks to invest and earn higher returns abroad and lastly, the introduction of more effective monitoring mechanisms provided commercial banks with the means of reducing relatively high level of bad debts.

It is however difficult to detect a clear relationship between concentration and profitability. Between 1989 and 1995 the relationship is positive and implies that greater industry concentration allowed the established firms to be more profitable, an outcome that lends credence to the SCP hypothesis. Extending this analysis to the period 1996-1997, it is observed that the concentration index declined while the profitability index increased. This outcome points to the lack of a positive relationship between profits and concentration and undermines the SCP hypothesis. Our experimentation of plotting market concentration against 
profitability confirms the finding that there is no discernable direct relationship between concentration and profitability (Figure 2). According to the SCP and ES hypotheses, one can expect to find a positive relationship between these two measures. However Greer (1980) notes that the positive relationship between concentration and profitability could be entirely spurious and might be due to other factors unrelated to market power. Figure 1 shows that until 1995, there is a positive relationship between concentration and profitability but no relationship afterwards. This suggests that in Botswana's case, the relationship between these measures could be influenced by factors other than market power.

Figure 2 The relationship between profitability and concentration

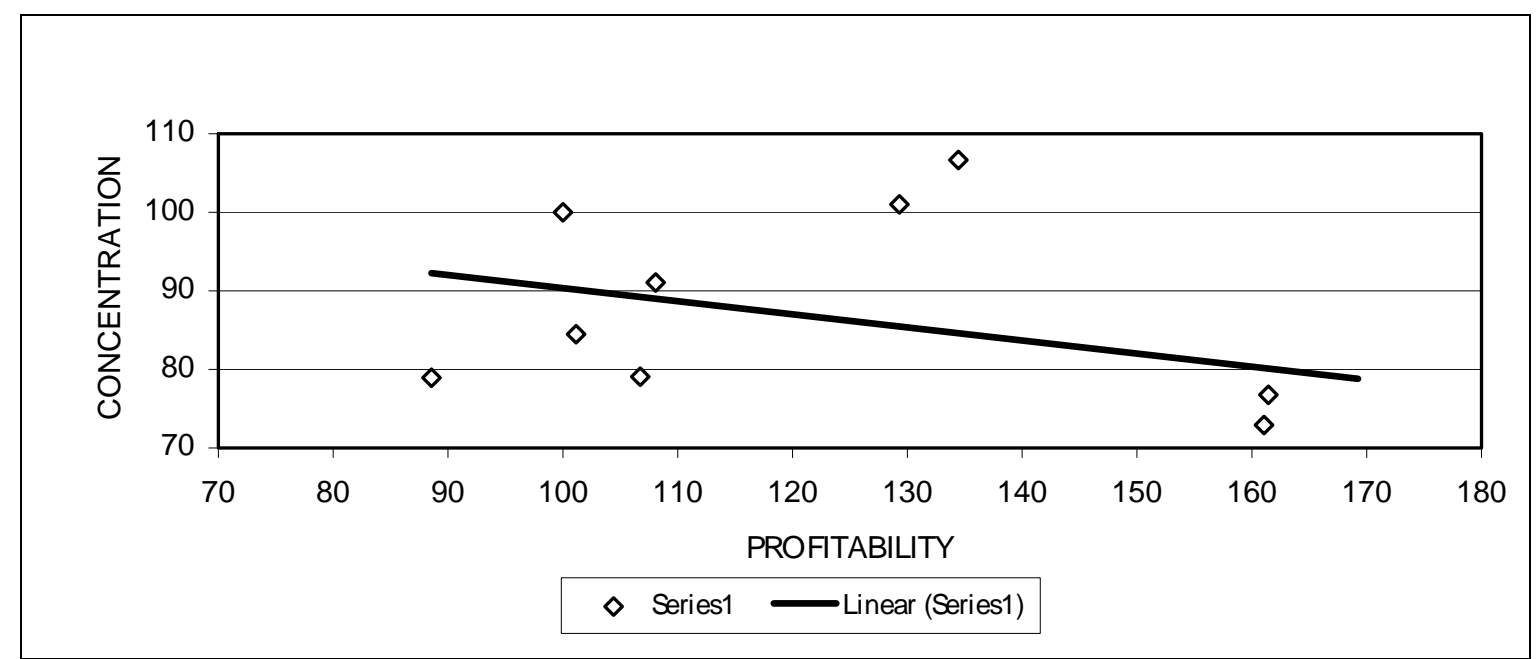

Source: BoB (2002)

\subsection{Productivity/Efficiency}

To calculate productivity, total earning assets and non-interest expenses of commercial banks are employed as proxies for output and input respectively (Figure 3). The increase in the ratio of earning assets to expenses between 1995 and 1999 can be linked to the rapid growth in commercial banks holdings of BoBCs which accounted for about 35-37 percent of total earning assets of commercial banks. 
Figure 3 Profitability of Botswana's banking sector, 1989-2001

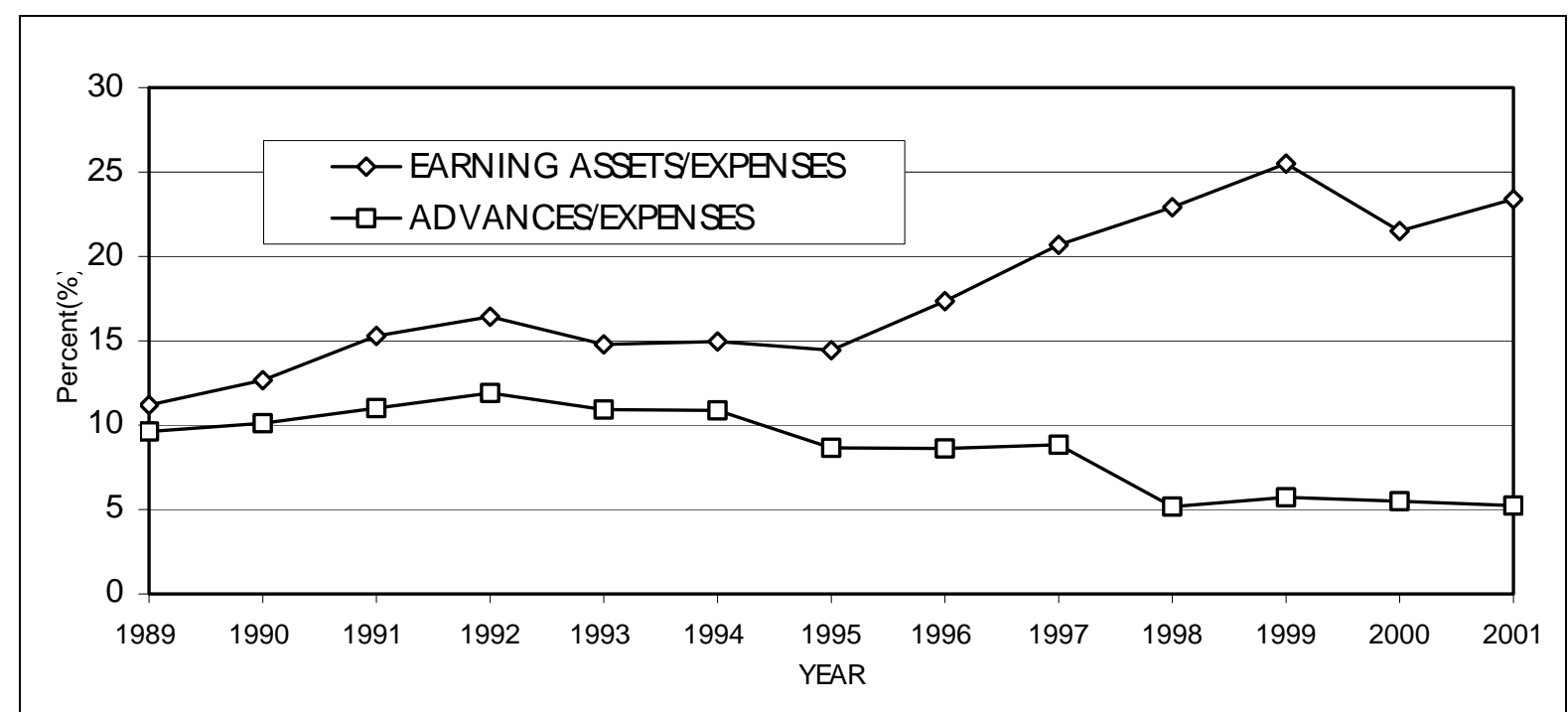

Source: BoB (2002)

As an alternative measure of productivity, we utilise the ratio of banks advances to expenses. The measure shows that productivity increased between 1989 and 1992, declined between 1992 and 1995 before stabilising over the 1995 - 2001 period. The use the two measures of productivity presents us with different sets of findings. Where earning assets are used as output, there has been an increase in productivity between 1996 and 1999. However, when advances are used as output, the measure shows that productivity declined in 1995 and there has only been a small increase in 1996 and 1998. This variation in results is partly due to the conceptual definition of bank "output", where bank output is broadly defined as the product (or service) of a bank. If a commercial bank's function is simply to attract deposits and then invest these funds in any assets that earn an income, then the former measure of output (total earning assets) is appropriate ${ }^{13}$. If instead a broader view is adopted and bank output is defined in terms of its primary intermediation function i.e. the transformation of deposits into loans, then the latter definition of output, advances, is appropriate. Using the intermediation definition of output that also represents an encompassing "developmental" view, it can be concluded that banks' efficiency has declined.

We expand our analysis and utilise deposits and advances as alternative measures of output while inputs are proxied by fixed assets. Productivity (or efficiency) is then quantified by the (inverse) ratio of advances to fixed assets or as the (inverse) ratio of deposits to fixed assets. It can be deduced from plotting these ratios that productivity more than doubled between 1989 and 1998. In 1989, the ratio of fixed assets to total deposits was 4.6 percent and by 2001, this ratio had decreased to less than 2 percent. When advances are used as a 
measure of output, the ratio decreased from 7.5 percent in 1989 to just over 3 percent in 2001.

Figure 4 Ratio of advances and deposits to fixed assets, 1989-2001

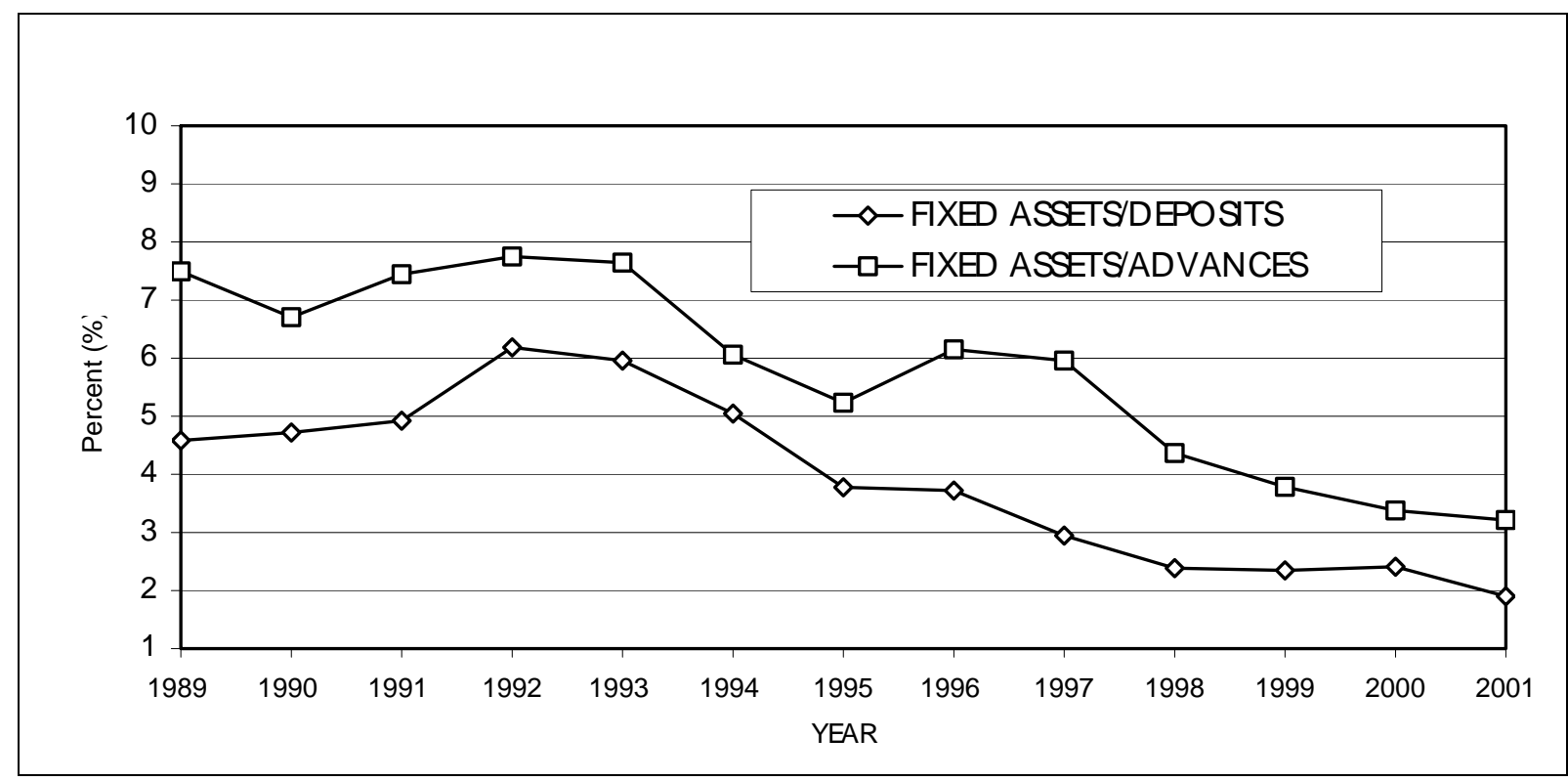

Source: BoB (2002)

The ratio of total earning assets to total labour costs can be interpreted as another measure that captures changes in productivity (Figure 5). Like the ratios used in Figure 4, this measure depicts a similar decline between 1993 and 1994. This was followed by a small recovery in 1995 before increasing rapidly until 1997. This increase coincides with the restructuring process conducted by existing banks to meet anticipated challenges from new entrants into the banking sector. The restructuring process had negative effects on banking sector employment. In September 1993, the financial (and business) sector employed an estimated 18200 workforce, a figure that declined by 6.6 percent to slightly over 17000 in 1994. By 1998, the number the employees had fallen to 16932 employees. Of these, financial intermediaries employed only 4739 workers, a figure representing a paltry 28 percent of total employees in the financial and business sector (CSO, 1998). An alternative measure, the ratio of advances to labour cost also shows a similar trend although not as dramatic as the ratio of earning assets to labour cost. 
Figure 5 Ratio of earning assets and advances to labour costs, 1989-2001

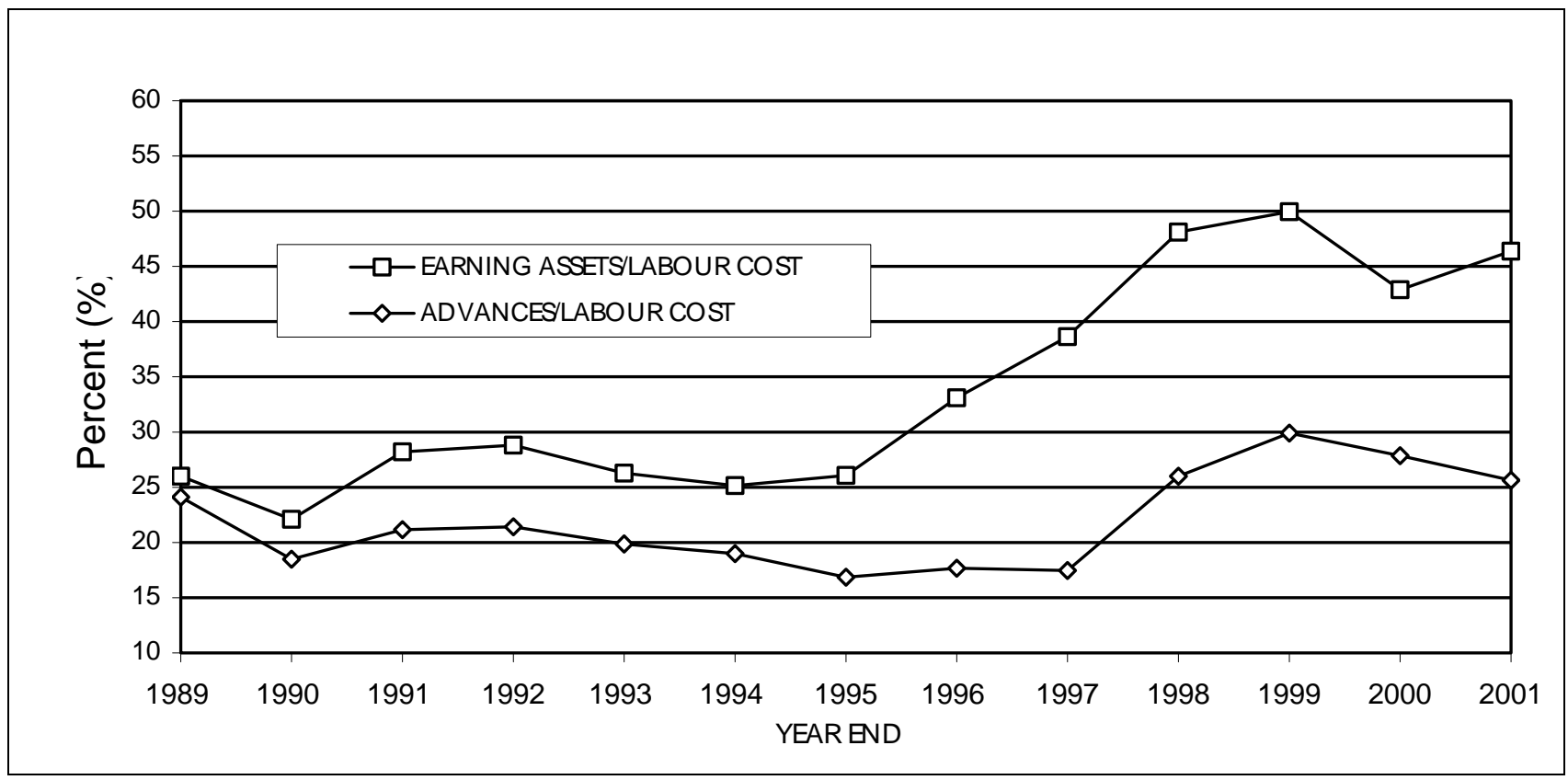

Source: BoB (2002)

\subsection{Non-interest income}

Figure 6 captures the trend of the ratio of non-interest income to total income. The ratio is used to establish the relative importance of non-interest income in total income of commercial banks. It is postulated that as the commercial banking industry becomes more competitive, the ratio should decline. This decline emanates from banks having to compete in providing services such as foreign exchange transactions which generate non-interest income. However, it is likely that with increased competition from non-bank financial institutions for non-interest income, commercial banks are likely to move from intermediation into other fee-earning services to retain or gain a substantial share of the market. This outcome results in a rise in the ratio of non-interest income to total income.

Figure 6, shows that until 1990, the commercial banking sector earned about 38 percent of its income from non-interest sources. The share of non-interest income in total income has however declined significantly since 1991, coinciding with the era of increased entry by newly licensed banks. By 2001, non-interest income accounted for just over 20 percent of total income of banking institutions. The decline in the ratio suggests that (i) liberalisation policies (such as the reduction, by the BoB, of previously high dealing margins of foreign exchange) have reduced commercial banks' non-interest income, and more importantly (ii) competition between commercial banks has increased without any explicit collusion in the market. Further evidence of the decline in relative importance of non-interest income in total banking operations is given 
by the decline in the ratio of non-interest income to total assets which declined from over 4 percent in 1989 to just over 3 percent by 2001(Figure 7).

Figure 6 Share of non-interest income in total income, 1989-2001

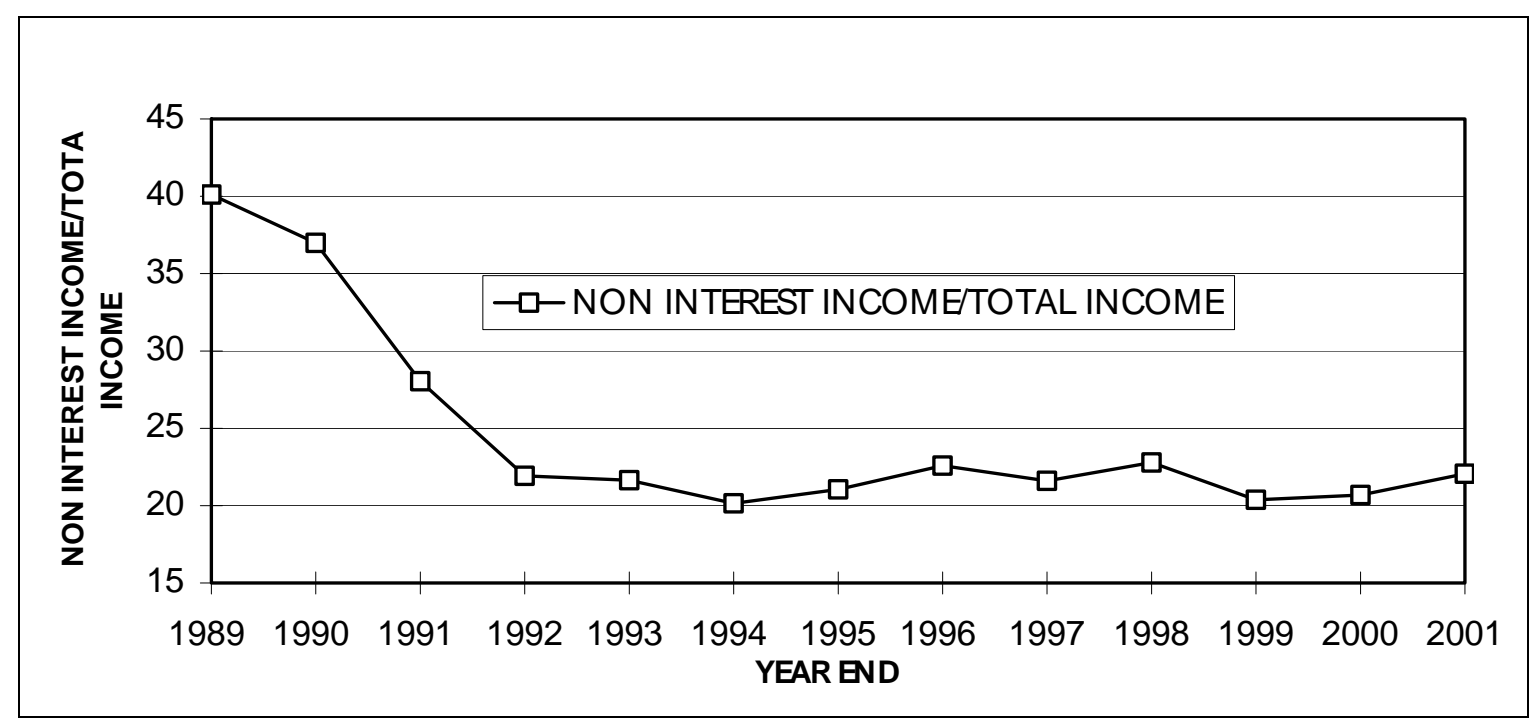

Source: BoB (2002)

Figure 7 Ratio of non-interest income to total assets, 1989-2001

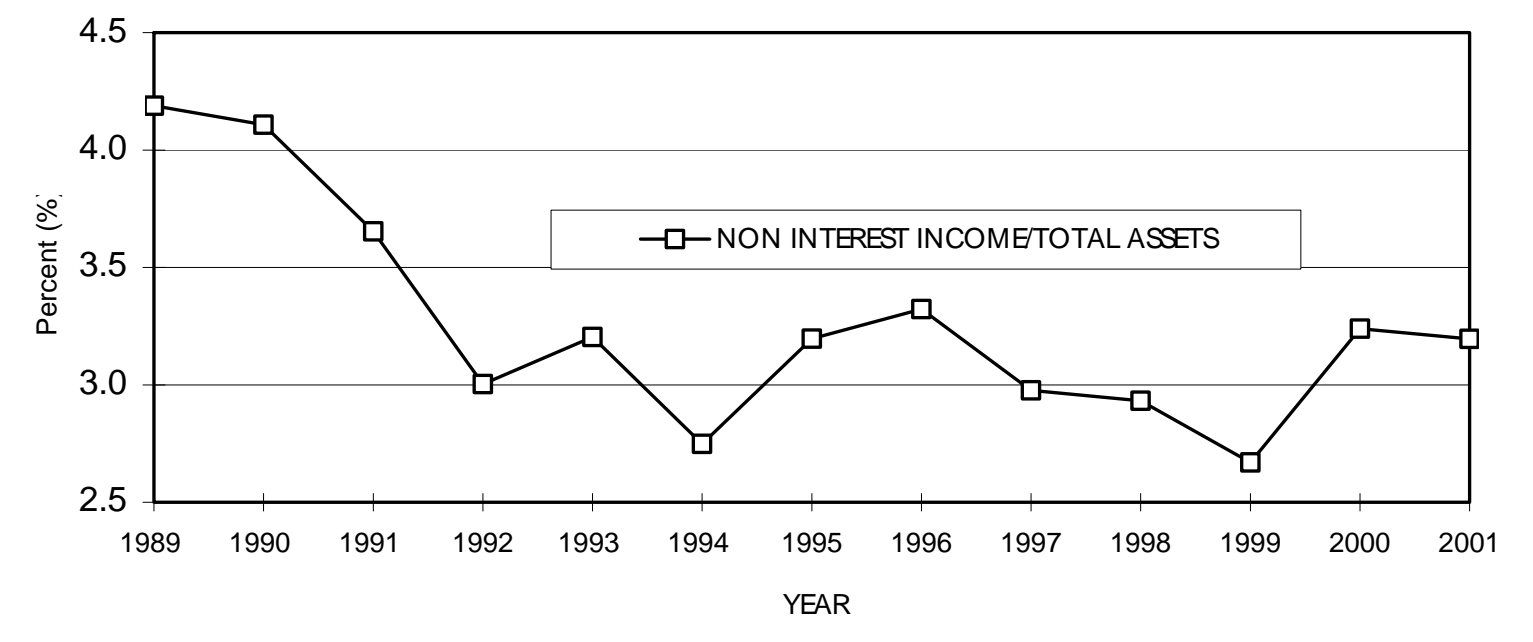

Source: BoB (2002)

\subsection{Intermediation}

A possible proxy for the returns from intermediation is net interest income (NNI). NNI is measured as the difference between interest earned from making advances and interest paid on deposits. In a concentrated banking sector, it is hypothesised that the interest rate on deposits would decline while the rate of interest on advances increases. The net result of these two effects will be a 
widening of the interest rate spread and an increase in net returns to banks. Figure 8 shows that between 1989 and 1991, interest spread declined to a low of one percent. This period coincided with the era when new banking firms (Zimbank and FNB) began competing with established firms (Barclays and Standard) for demand deposits. At present, the interest spread stands at about 5 percentage points.

\section{Figure 8 Commercial bank interest spread in Botswana, 1980-2000}

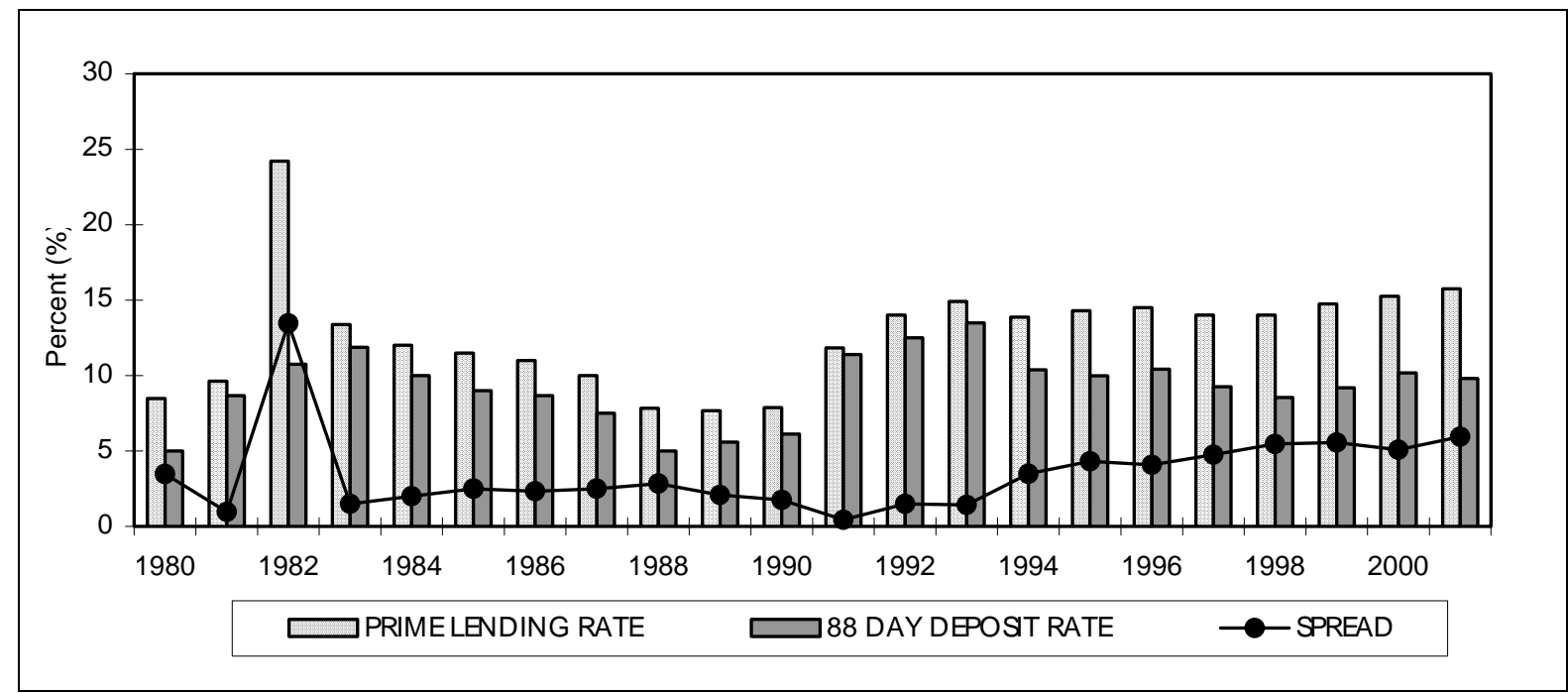

Source: IMF (2002)

For further analysis of the relative importance of interest income, we plot two alternative measures, the ratio of net-interest income to total earning assets, and the ratio of net-interest income to advances (Figure 9). While the first measure displays a relatively constant trend, one observes that apart from a period of decline between 1997 and 1999, the ratio of net interest income to advances depicts an increasing trend. The increase in this ratio probably reflects the increase in interest spread as commercial banks' interest income increased, a finding congruent with that depicted in Figure 8. Figures 8 and 9 both lend credence to the fact that in recent years, interest rate spreads in Botswana's banking sector have been on an upward trend.

More insight into the intermediation function of the banking sector can be gained by assessing the proportion of total bank deposits lent out to customers (or the general public). Two possible proxies for measuring this variable are net-interest income and total outstanding advances as proportions of total deposits respectively. Both ratios exhibit a similar upward trend between 1989 and 1994 (Figure 10). Between 1994 and 1997, the ratio of advances to total deposits declined from 80 percent to 47 percent, a result indicating a decline in intermediation functions of commercial banks. However, a more plausible reason for this decline could be the substantial revenue inflows from diamond 
exports. The large revenue inflows have caused significant increases in per capita income and ensured that since the mid-1980s, growth of deposits from the general public have outstripped credit advances made to the public ${ }^{14}$.

Figure 9 Ratio of net-interest income to advances and earning assets, 1989-2000

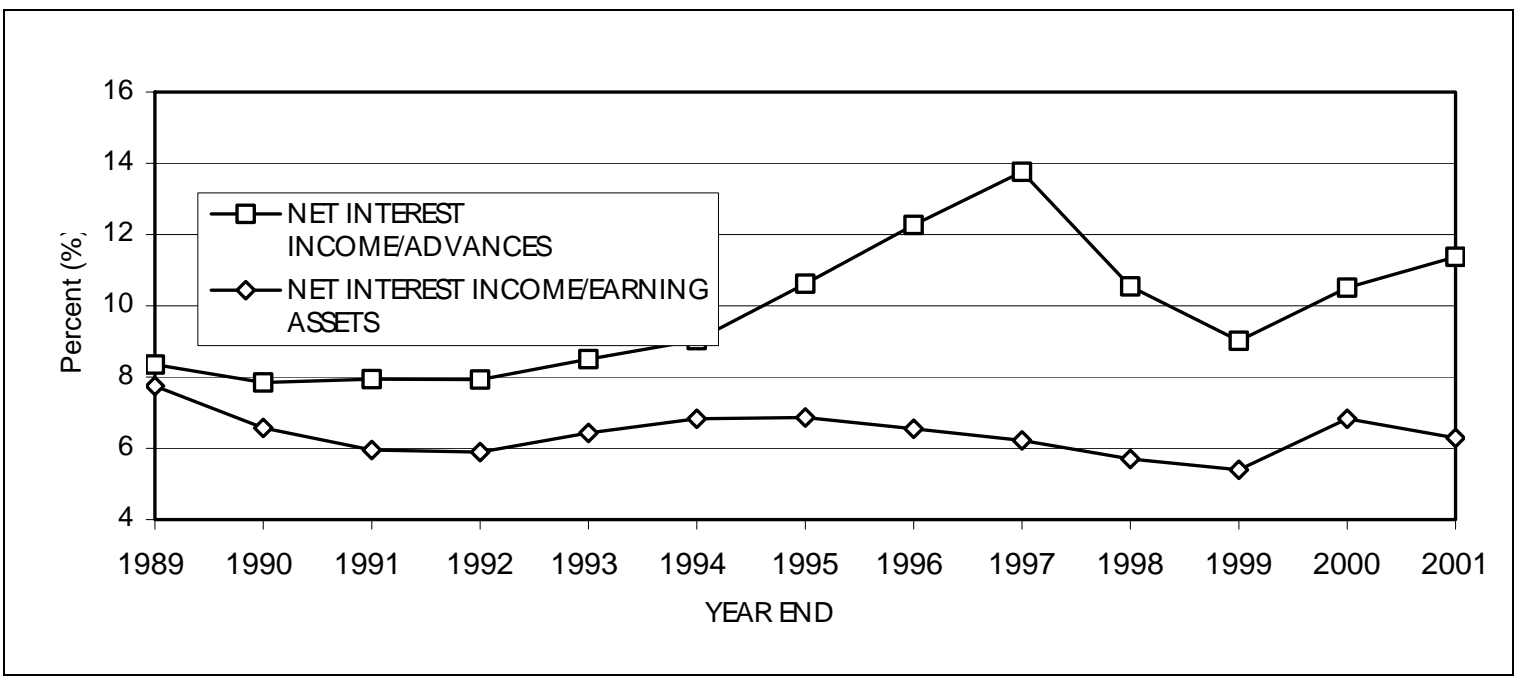

Source: BoB (2002)

Figure 10 Ratios of Net-Interest Income and Advances to Deposits, 19892001

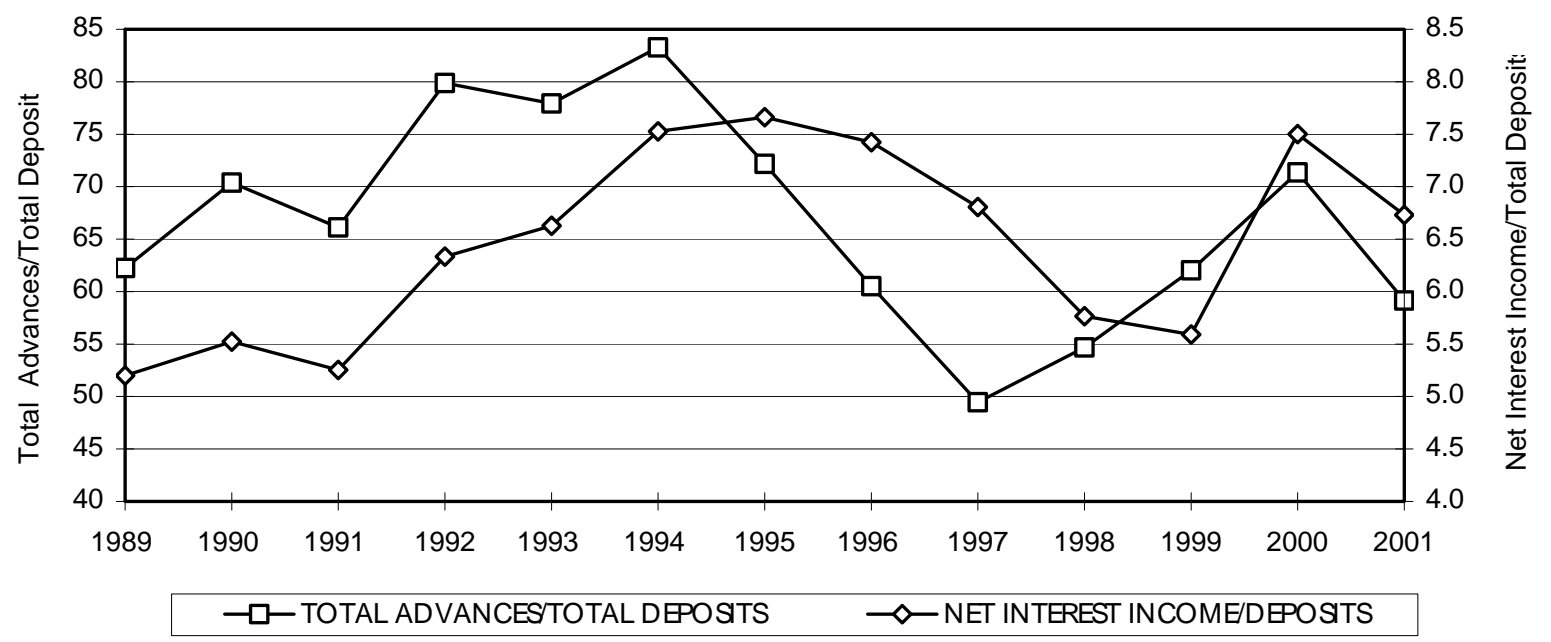

Source: BoB (2002)

The ratio of net-interest income to total deposits shows that despite a reduction in loan advances to the public, commercial banks managed to maintain high netinterest income. This finding provides additional evidence that the commercial banking sector in Botswana has a high interest rate spread owing to less market 
competition. It could however be argued that high interest spreads are not symptomatic of high market concentration but, are simply indicative of greater efficiency on the part of commercial banks in conducting their operations. The high interest spread could also be linked to the introduction of BoBCs. These certificates have afforded commercial banks an opportunity to invest deposits in a financial asset that yields a return exceeding interest payments made to holders of interest earning demand deposits.

\subsection{International comparison}

The finding from section 4.5 seems to suggest that Botswana's commercial banking sector is relatively uncompetitive. In this section, we briefly conduct an arbitrary comparison of interest rate spreads in Botswana with those in a number of developed and developing countries which have competitive banking markets. While the interest rate spread in Botswana has increased it still compares favourably when viewed alongside global trends. Figures 11 and 12 show the interest rate spread for number of countries (including Botswana) between 1996 and 1997. From a global perspective, countries with high inflation rates tend to have high interest rate spreads. On the other hand countries such as Japan, Malaysia, the United Kingdom and the United States with relatively low levels of inflation tend to have low interest rate spreads ${ }^{15}$.

Figure 11 Interest rates and spreads in 1996 for selected countries

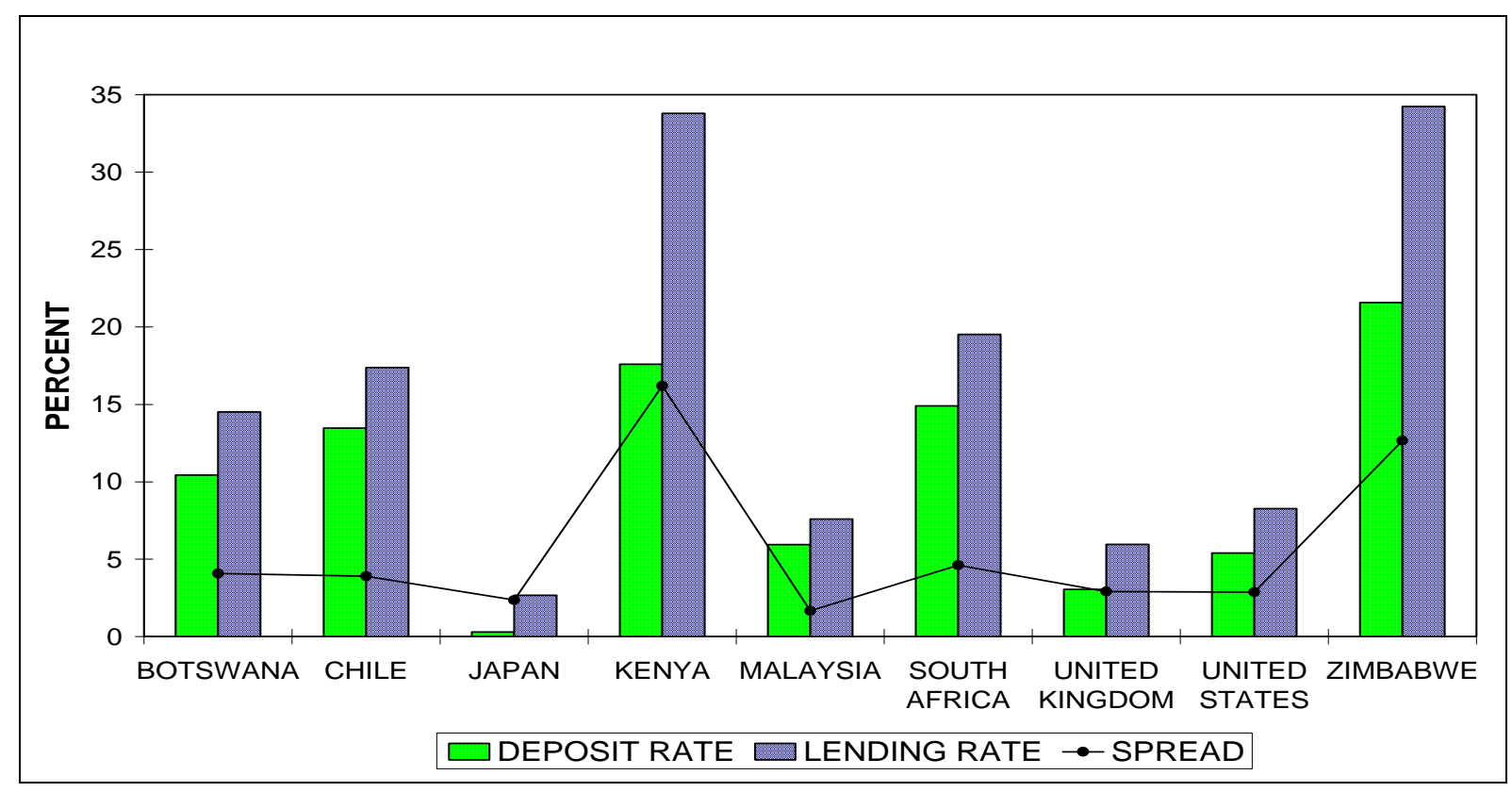

Source: IMF (1998) 
Figure 12 Interest rates and spread in 1997 for selected countries

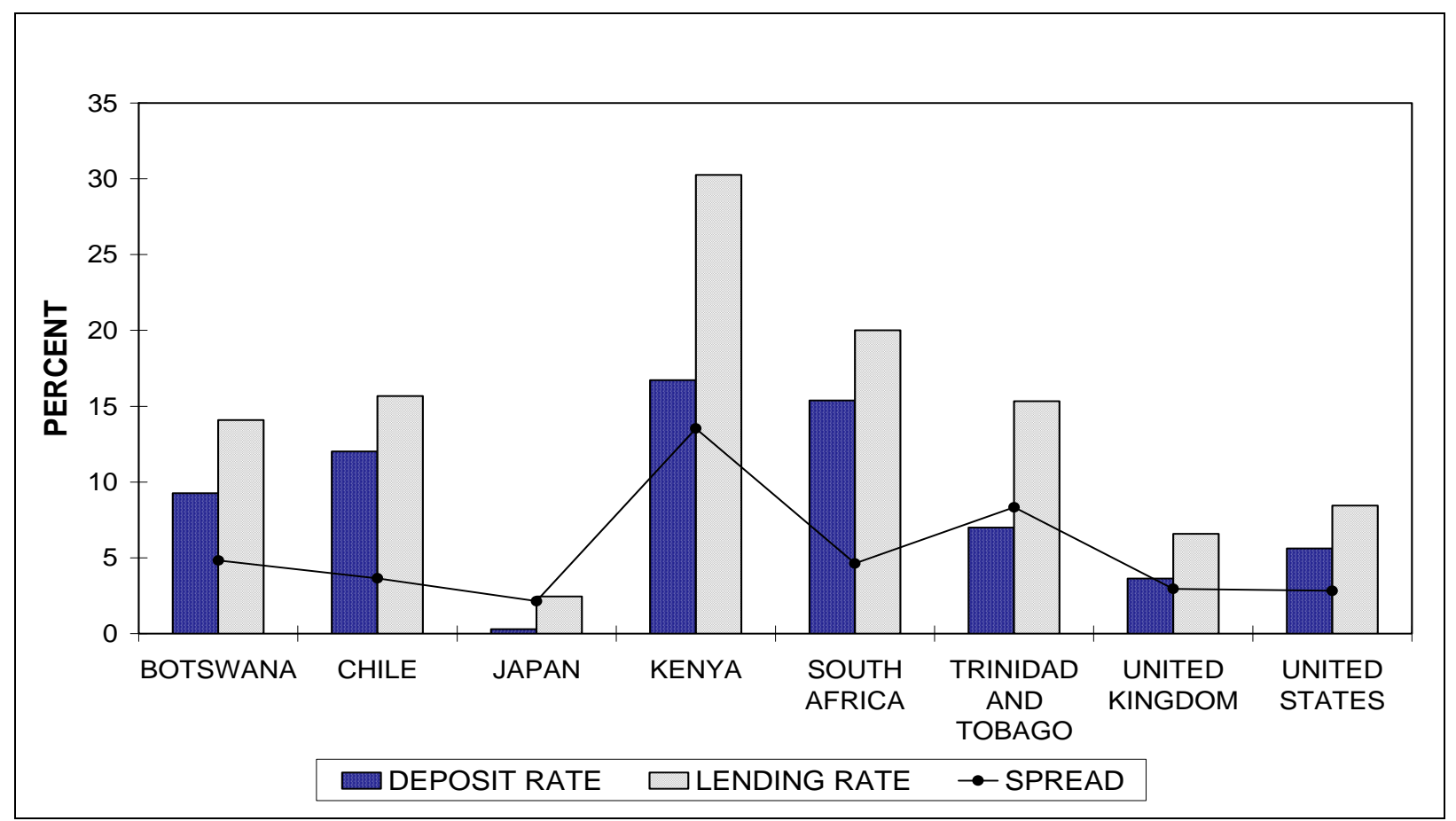

Source: IMF (1998)

\subsection{Maturity of advances}

Figure 13 indicates that a high proportion of advances made by commercial banks in Botswana have a maturity of between one and five years. Overdrafts and loans with maturity of less than a year account for more than fifty percent of total advances made by the banking sector. Although advances of long-term loans are now less than 20 percent of total advances, their share has increased steadily since 1988, an indication that over the years, commercial banks have become better equipped for evaluating risky projects. The development of better appraisal methods in screening loan demands has enhanced the banking sector's willingness to finance riskier, longer-term projects. It is also useful to note that the move towards advances with longer maturity terms is a likely contributory factor to the increase in the interest rate spread. It can thus be posited that, commercial banks have been able to earn high returns from advances derived from improvements in efficiency ${ }^{16}$ and better appraisal methods. 
Figure 13 Share of advances by maturity in total outstanding advances 1989-2001

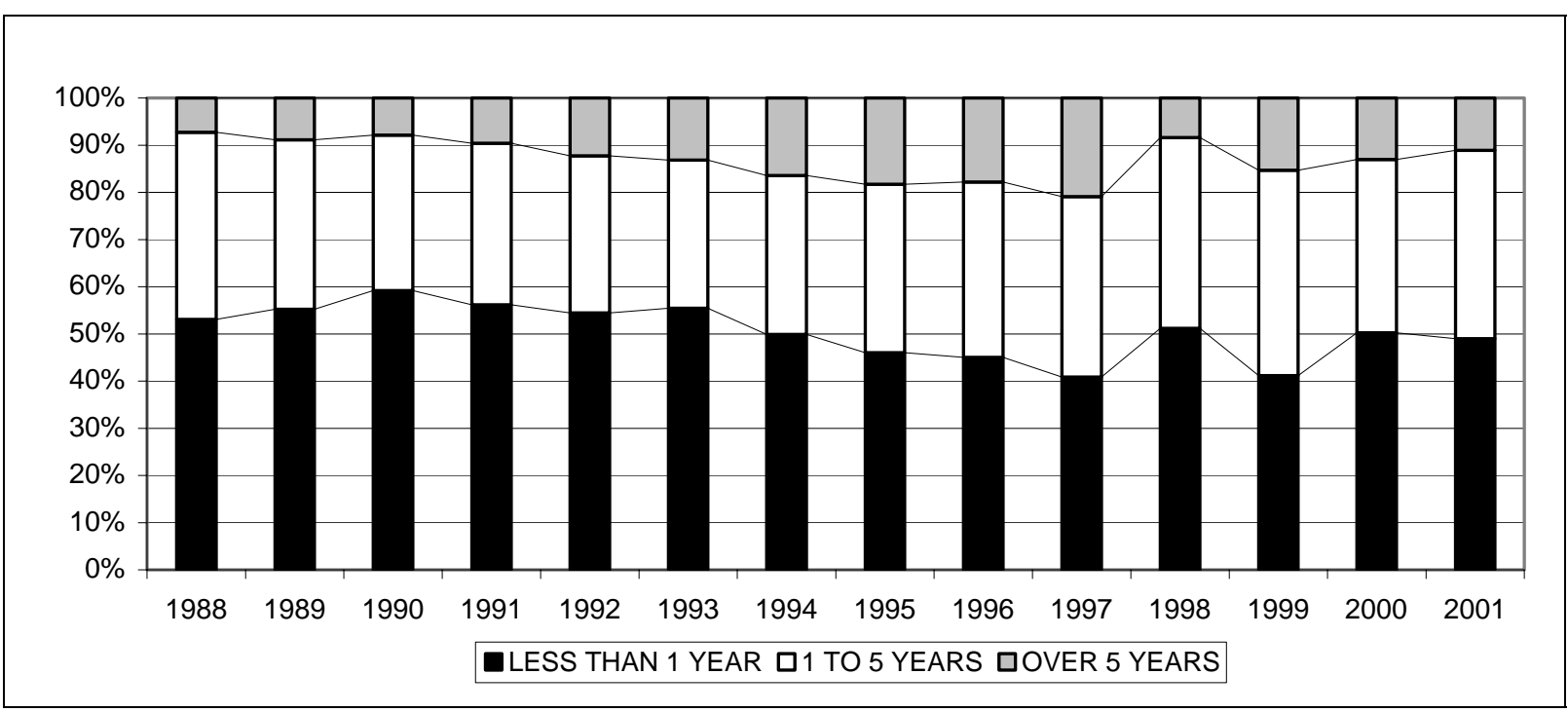

Source: BoB (2002)

While advances with maturity of less than one year still account for more than 50 percent of total advances, this proportion has gradually decreased since 1990 . The decrease could be due to increased competition, a factor that has geared banks to (i) compete for customers using a variety of innovative banking services, and (ii) increase lending on the medium and long term basis to earn higher interest income ${ }^{17}$. Along with better appraisal methods, the increase in loans of longer maturity could also be traced to commercial banks now extending the maturity period and attaching less stringent lending conditions on loans (especially mortgage and car loans) to households. The application of less stringent loan conditions is mainly due to employers guaranteeing these types of lending, a move causing banks to view longer-term mortgage and car loans as less risky. Therefore, it can be hypothesised that the increase in banks' long term lending might not reflect any change in the banks efficiency but an increase in demand for loans by households.

\section{CONCLUSIONS AND RECOMMENDATIONS}

The market concentration doctrine and efficient structure hypotheses suggest a positive relationship between concentration and profitability, although they differ on the causal relationship. For the banking sector in Botswana, two distinct periods are observed. These are (i) the period between 1989 and 1995 when the relationship between concentration and profitability is positive, and (ii) the period between 1996 and 2001 when concentration declined (indicating increased competition) and profitability increased. Both these findings 
undermine both theories at least in the case of Botswana's banking industry. However, the outcome is consistent with the X-efficiency hypothesis, which states that firms do not produce at the maximum possible level of efficiency when competition is weak. If output is measured in terms of total deposits attracted, it can be argued that prior to 1996, commercial banks in Botswana were X-inefficient as they could have produced more output with fewer inputs (or they could have used fewer inputs to produce the same level of output). With the banking sector embarking on a retrenchment exercise in the early 1990s, it can be argued that its staff complement (inputs) was lower and as a consequence, its output (deposits) should have increased.

With respect to efficiency, we can conclude that competition has increased efficiency in the banking sector causing an increase in its level of profitability. However, when advances are used as an alternative measure of banks' output, efficiency in the banking sector has declined, even though competition has increased. In the case of homogeneous products such as foreign exchange transactions and chequebooks for which prices are easily comparable between banks, we find evidence of increased competition between banks ${ }^{18}$. Competition has also reduced the importance of non-interest income as evidenced by the decline in the ratio of total income to total assets. On the other hand, it is difficult to ascertain whether competition for heterogeneous products such as loans has increased mainly because of changes to the price of loans, i.e. interest rates and other factors such as collateral and repayment periods. The change in entry regulations has encouraged new banks to establish a presence in Botswana's banking sector leading to a reduction in concentration and has fostered competitive practices among banking institutions.

While the initial impact of liberalisation in terms of entry was somewhat limited owing to the small size of new firms relative to the established banks of Barclays and Standard Chartered, recent mergers and acquisitions made by both FNBB and Stanbic Bank have not only ensured that their previous dominance of the established firms is being challenged but also resulted in the introduction of a range of innovative financial services being offered, thereby benefiting consumers. The policy lesson of our findings is easily appreciated. While Botswana has been economically buoyant in the past three decades, it still remains highly dependent on earnings from diamond exports. Government's strategies to diversify the economy away from diamonds will be greatly enhanced by policies which encourage financial institutions to deliver their specialised financial services at minimal costs. Commercial banks also need to be encouraged to avail some of their excess liquidity and provide credit for long term investment. The government could also use commercial banks as a conduit for channelling some of its surplus revenues towards asset formation in potential growth areas of manufacturing, transport and tourism. 


\section{ENDNOTES}

1 The RMA consists of countries that utilise the South African Rand as a common currency and implicitly implement the monetary policies of South Africa. With the exception of Botswana which pulled out in 1976, the RMA includes all the countries of the Southern African Customs Union, these being Lesotho, Namibia, Swaziland and South Africa.

2 Although incorporated locally, both Barclays Bank and Standard Chartered Bank are 100 percent owned and controlled by the main headquarters located in Britain.

3 The excess liquidity was banked in a special account known as the "call account". From its inception in 1978 until its scrapping in 1991, the account offered commercial banks an interest rate of 3.5 percent.

4 This was later reduced to P100 000.

5 As noted by Jefferis (1991), in many financially repressed economies, negative real interest rates are imposed to encourage investment and are associated with a shortfall of savings. In Botswana's case however, the negative real interest rates are atypical of financial repression as they could be traced to the inflow of resources from diamond exports and were associated with an overall surplus of savings.

6 BoBCs are essentially 3-month and 6-month treasury bills sold at a discount to the general public at regular auctions.

7 This outcome is also advanced by the theory of contestable markets.

8 Where interest rates can be regarded as the price of loans.

9 However, Gilbert (1984) observes that the few studies that have tested the collusion hypothesis have reported inconsistent results.

10 This index is based on the relative market share of all firms in the industry.

11 These companies also doubled as customers of the parent bank in South Africa.

12 Profits are calculated as the ratio of total commercial bank pre-tax net income to total assets.

13 This function best reflects shareholders' perspective of bank output, and the recent rise in profitability and efficiency is hence reflected in rising bank share prices over 1997 and 1998.

14 An additional (and related) factor is that the government has set up a number of schemes (such as the financial assistance programme) and institutions (like the National Development Bank) aimed at granting citizens the opportunity to access capital funds at low interest rates. These, to some extent, reduced the need for approaching banks for capital under more stringent lending conditions. 
15 The positive correlation between inflation and interest rate spread might reflect the need to compensate firms for conducting business in an unstable financial environment.

16 Where efficiency is measured using earning assets.

17 However, it should be noted that banks still favour financing household consumption, which accounts for more than a third of total commercial banks' lending.

18 Competition has also come from non-bank financial institutions such as licensed bureaux de change.

\section{REFERENCES}

1 AGU, C. C (1992) "Analysis of the determinants of the Nigerian banking system's profits and profitability performance", Savings and Development, 4(XVI).

2 BANK OF BOTSWANA (1993) Annual Report, Gaborone.

3 BANK OF BOTSWANA (Various years) Botswana Financial Statistics, Gaborone.

4 BELL, F.W. \& MURPHY, N.B. (1969) "Impact of market structure on the price of a commercial banking service", The Review of Economics and Statistics, 51(2).

5 BROWNBRIDGE, M. \& HARVEY, C, (1998) Banking in Africa, Africa World Press: Trenton.

6 CENTRAL STATISTICS OFFICE (1998) Statistical Bulletin, Gaborone.

7 CLARK, R. (1985) Industrial Economics, Blackwell Publishers.

8 DEMSETZ, H. (1973) "Industry structure, market rivalry and public policy”, Journal of Law and Economics.

9 GREER, D (1980) Industrial Organisation and Public Policy, (2nd ed.) Macmillan Publishing Company.

10 GILBERT, A.R. (1984) "Bank market structure and competition: a survey", Journal of Money, Credit and Banking, 16(4).

11 HARBERGER, A.C (1954). "Monopoly and resource allocation (in factor markets versus product markets)", American Economic Review, 44(2).

12 INTERNATIONAL MONETARY FUND (2002) International Financial Statistics, Washington DC.

13 INTERNATIONAL MONETARY FUND (1998) International Financial Statistics, Washington DC.

14 JEFFERIS, K. (1991) "An unusual case of financial deepening: financial reform and economic development in Botswana", Seminar Paper of the Department of Economics, University of Botswana.

15 LEIBENSTEIN, H. (1966) "Allocative efficiency vs. X-efficiency", The American Economic Review. 
16 ROBERTS, S. (1994) "Competition in banking", Research Bulletin, Bank of Botswana.

17 SHAFFER, S. (1993) "A test of competition in Canadian banking" Journal of Money, Credit and Banking, 25(1).

18 SMIRLOCK, M. (1985), "Evidence on the (non) relationship between concentration and profitability in banking” Journal of Money, Credit, and Banking, 17(1). 